\title{
Interactive comment on "A joint probabilistic index for objective drought identification: the case study of Haiti” by Beatrice Monteleone et al.
}

\section{Beatrice Monteleone et al.}

beatrice.monteleone@iusspavia.it

Received and published: 16 January 2020

The authors would like to thank Dr. Stavros Yannopoulos for his positive feedback on the manuscript. All his remarks were useful to improve the paper readability and have been addressed in the revised version of the manuscript.

Interactive comment on Nat. Hazards Earth Syst. Sci. Discuss., https://doi.org/10.5194/nhess2019-296, 2019. 